\title{
Perception of the Recipients on the 4Ps Poverty Alleviation Program in the Philippines
}

\author{
Alma Sonia Q. Sanchez-Danday, Lorena M. Ripalda \\ Maria Teresa L. Delima, Romyr L. Gabon
}

\begin{abstract}
To alleviate poverty in the Philippines, the governmen implemented the PantawidPamilyang Pilipino Program (4Ps) which has been patterned from the Conditional Cash Transfer (CCT) Programs from other countries. This study sought to determine the recipients' profile and its relationship to their perceived program implementation in terms of its policy and objectives through a descriptive correlational study. Thirty-nine recipients from one public elementary school answered the questionnaire based on the PantawidPamilya Guide Booklet by the Department of Social Welfare and Development. Statistical tools such as eta correlation coefficient, Pearson's product-moment correlation coefficient, and Goodman and Kruskal's gamma were used to establish the relationship between the recipients' profile and perceived extent of implementation at $5 \%$ level of significance. The recipients' profile was determined using mean, percentages, and frequency distribution. The results revealed that the program's health and education policies and its social assistance and development objectiveswere perceived to be implemented, however, only a few profile factors were significant to the recipients' perceived program implementation.
\end{abstract}

Index Terms: poverty alleviation, policy implementation social services, 4Ps

\section{INTRODUCTION}

The Philippines is one of the third-world countries with Filipinos living below the poverty line, thus affecting the country's economic development. During the past administration of Fidel V. Ramos, his battle cry was "Poverty Alleviation Through People Empowerment" with the cooperation from the government and private sectors sharing a common scheme. It was during the $1^{\text {st }}$ National Congress of People's Organization in 1993 held in Cebu City, Philippineswhen all issues faced by the country were presented to serve as a jump off start to give appropriate solutions to the country's economic problems. However, it was during President Gloria Arroyo's administration when the local government actedthrough a poverty alleviation program.

Executive Order No. 221 of 2003, amending Executive Order No. 15, series of 1998, mandated the Department of Social Welfare and Development (DSWD) to assist the Local Government Units (LGUs) in implementing povertyalleviation programs, projects, and services. The DSWD implemented the PantawidPamilyang Pilipino Program

Prof. Alma Sonia Q. Sanchez-Danday, College of Education, Leyte Normal University, Tacloban City, Philippines.

Prof. Lorena M. Ripalda, College of Education, Leyte Normal University, Tacloban City, Philippines.

Prof. Marial Teresa L. Delima, College of Education, Leyte Normal University, Tacloban City, Philippines.

Prof. Romyr L. Gabon, College of Arts and Sciences, Leyte Normal University, Tacloban City, Philippines.
(4Ps) patterned from other Latin American countries such as Mexico, Brazil, Honduras, Jamaica, and Nicaragua which have implemented their own Conditional Cash Transfer Programs effective since the late 1990's [1].This program was designed to promote human capital accumulation among the poor households through the provision of cash grants. This initiative was in consonance with the constitutional mandate[2] for the state to establish policies that will improve its citizens' quality of life.

\section{A. Review of Related Literature}

Reference [3] was about the quality of education and the outcome of the socio-economic status of some countries as factors that are linked with economic productivity of a nation. Results showed that there are still some issues that have to be addressed regarding the investment in education quality. Factors that help individuals to be socially productive in the future include the quality of education and the socio-economic status of the family.

In the Philippines, education plays an important role in one's life. In order to determine the status of having good education, school quality and family background on the children's achievement plays an important role.

A study conducted found school conditions to affect the academic achievement of students [4]. Students perform much better if schools have the basic facilities. Reference [5] which studied the correlation between the influence of school quality of elementary education and the national GNP per capitafound that schools provided with higher funding perform better than schools with little or minimal financing. Countries with citizens having higher levels of education were also found to have a boost in its economic status [6].

The Philippine government believes that acquiring education and good health is a means of alleviating poverty and that poor families would benefit from the 4Ps initiated by the government. Several studies then about the 4Ps ensued in the country.

The study of Catubig, Villalino, and Dollery[7]focused on the administrative efficiency of the program and found the use of program funding to be efficient though implementation may not be cost-efficient.

Studies, likewise, attempted to track the academic performance and school outcomes of 4Ps recipients finding a significant increase in school enrolment, attendance, and completion rate $[8,9,10,11,12,13,14,15]$. The recipients were also found to be motivated to study following adequate provision of school requirements and allowance [13].

Studies also found the need to improve the services for the recipients such as the provision of health supplies as well as access to health care providers [11]. Reference [16]stressed the expectation to improve recipients nutritional status through the various services offered under the 4Ps. A more recent study, however, revealed a 
significant reduction on the number of malnourished children-recipients, improvement of healthcare services for pregnant women, and a decrease in child labor cases [17].

Several implementation challenges were also enumerated such as the dearth of available resources [18]. The study further stressed the need to conduct monitoring and evaluation studies to improve 4Ps mechanisms in choosing the recipients and in addressing policy loopholes and deficiencies.

\section{B. Objectives of the Study}

The study attempted to investigate the implementation of 4Ps in Tacloban City, Philippines.

Specifically, the study sought to answer the following questions:

1. What is the profile of the 4Ps recipientsaccording to position in the family, educational attainment, and eligibility of recipients?

2. What is the extent of the implementation of the 4Ps in terms of its program conditions on health and education and its objectives on social assistance and social development?

3.Is there a significant relationship on the profile of the recipients and theextent of implementation of the 4Ps?

\section{THEORETICAL/CONCEPTUAL FRAMEWORK}

The dynamic "Solow Growth Model" named after the economist Robert Solow[19] describes how the economy changes and grows over time particularly as saving and investment. This model consists of variables, behavioral relationships, and equilibrium conditions related to the different variables in this study. Behavioral relationships, in relation to this study, are the ways how the recipients utilize the financial aid provided by the government. The equilibrium conditions happen once there is marked improvement in the recipients' conditions and savings from their community projects.

Another theory in which this study can be anchored on is the Ragnar Nurkse's Balanced Growth Theory [20]. The economic investment processin this theory is equivalent to the investment in the form of financial assistance given by the government to the 4Ps recipients. The process ends whenthe economy grows and develops attributed to the change of economic conditions of the recipients. Likewise, the developmental stages in the economic growth theory [21]shows that marked improvement will take place when a poverty alleviation program is well-implemented.

The framework of this study is quite similar to a study [22] involving financiers, providers, and beneficiaries. However, in this paper, the government serves as both the financiers and providers while the beneficiaries are the 4Ps recipients.

To implement the program, several factors were considered including the profile of the recipients. Another factor is their eligibility to the program. This profile of the recipients may possibly be significant to the extent of implementation of the 4Ps policy and objectives.

The schematic diagram in Figure 1 shows the one-way flow of this study.

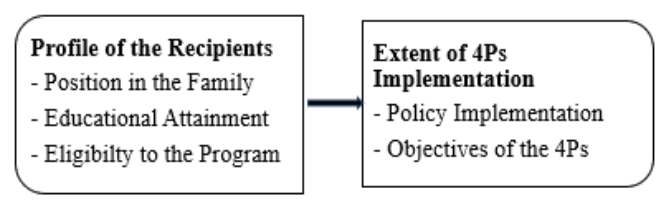

Figure 1. The conceptual framework of the study.

\section{A. Null Hypothesis}

This study advanced the null hypothesis that no significant relationship exists between the profile of the recipients and the extent of implementation of 4Ps.

\section{METHODOLOGY}

The descriptive-correlational design was used in this study. Thirty-nine recipients answered the guided questionnaire. These recipients reside in one barangay with children studying in one public elementary school in Tacloban City, Philippines.

Aguided questionnaire was used to gather information on the recipients. This questionnaire was based on the PantawidPamilya Guide Booklet by the DSWD. An overall Cronbach's alpha of .71 was derived from the results of the pilot test making the instrument "acceptable" for social science research.

Prior to the conduct of the survey, the researchers sought a written permission and then arranged for the administration of the guided questionnaire from the barangay chairman where the study was conducted and the school principal where the student recipients study.

A short briefing about the survey questionnaire, purpose of the study and the method in answering the questionnaire was made. The questionnaires were personally administered by the researchers. Confidentiality of responses was observed. The researchers ensured that relevant items in the questionnaire were answered completely.

Statistical tools such as eta correlation coefficient, Pearson's product-moment correlation coefficient, and Goodman and Kruskal's gamma were used to establish the relationship between the recipients' profile and perceived extent of implementation at 5\% level of significance. The recipients' profile was determined using mean, percentages, and frequency distribution.

The Pearson's $r$ was used to show the relationship between the number of household members and implementation of 4Ps policy and objectives while gamma was used to show the relationship between the household monthly income and implementation of 4Ps policy and objectives. The other factors in the profile such as position in the family, educational attainment, housing, occupation, and ownership of land and house, water source, electricity connections, and sanitation facilities and their relationship to the program's policy and objectives were established through the eta correlation ratio.

\section{RESULTS AND DISCUSSION}

\section{A. Profile of the 4Ps Recipients}

The profile of the 4Ps recipients includes: position in the family, educational attainment, and eligibility. Eligibility includes number of years of residency in the barangay, number of household members, economic indicators such as types of housing, occupation, and household monthly 
income, ownership of assets, and access to water, electricity, and sanitation facilities.

\section{Position in the Family}

Figure 2 shows that from among the 39 respondents, $84.62 \%$ (33) are mothers, $12.82 \%$ (5) are fathers, and only $2.56 \%$ (1) are guardians of the children.

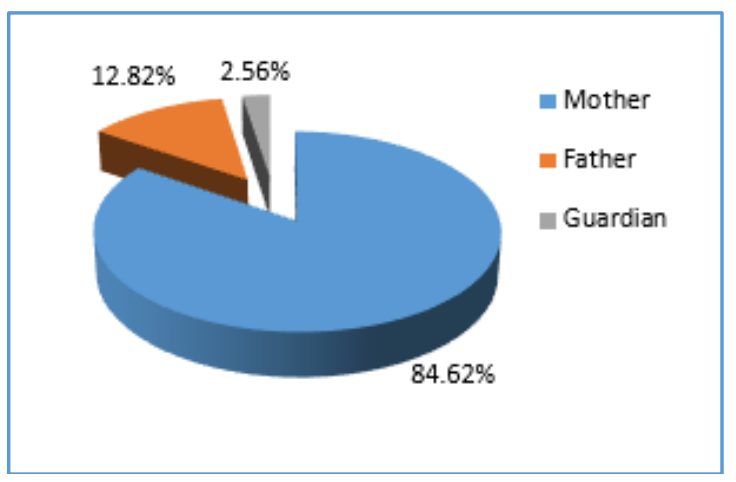

Figure 2. Position in the family of 4Ps respondents

\section{Educational Attainment}

Figure 4 shows that $41.03 \%$ (16) of the respondents reached high school level, $23.08 \%$ (9) for elementary level, $12.82 \%$ (5) both for elementary and high school graduates, $7.69 \%$ (3) reached the college level, and only $2.56 \%$ (1) graduated from college.

\section{Years of Residency in the Barangay}

Most of the respondents have lived in the barangay for five years and above. This group comprises $94.87 \%$ (37) of all respondents as shown in Figure 3. Only 5.13\% (2) have lived for three years. No one from among the respondents has lived for two years and less in the barangay.

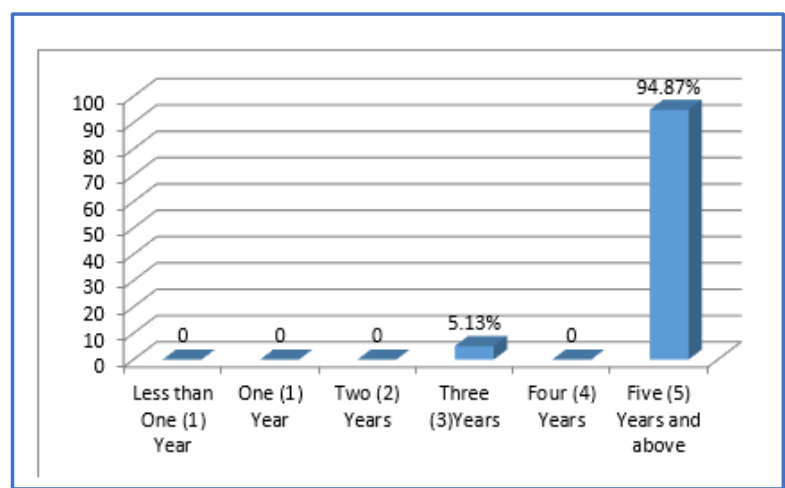

Figure 3. Number of years of residency in the barangay Number of Household Members

Figure 5 shows that households with five to seven members comprise $20.51 \%$ (8) each. This is followed by four members comprising $12.82 \%$ (5) and those with three household members comprising $7.69 \%$ (3). Those with eight and ten members each comprise $5.13 \%$ (2) and household members of two, nine, and eleven comprise $2.56 \%$ (1), respectively.

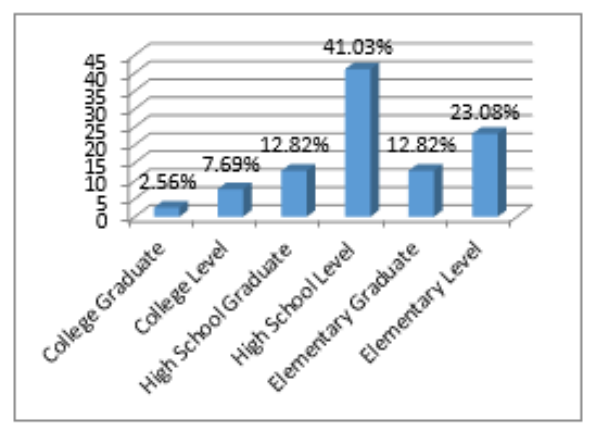

Figure 4. Educational attainment of 4Ps respondents

The researchers further categorized the respondents' educational attainment as shown in Table 1. This table shows that all respondents have entered school. However, only three reached college level and only one earned a degree. It can be observed as well that only the mothers pursued to graduate from high school and even in earning a degree.

Table 1. Educational attainment of 4Ps respondents and their position in the family

\begin{tabular}{|c|c|c|c|c|c|c|c|c|c|}
\hline \multirow{7}{*}{ Position } & & \multicolumn{6}{|c|}{ Educational Attainment } & \multirow{2}{*}{ Total } & \multirow{2}{*}{$\%$} \\
\hline & & $\begin{array}{c}\text { College } \\
\text { Graduate }\end{array}$ & $\begin{array}{c}\text { College } \\
\text { Level }\end{array}$ & $\begin{array}{c}\text { HS } \\
\text { Graduate }\end{array}$ & $\begin{array}{c}\text { HS } \\
\text { Level }\end{array}$ & $\begin{array}{c}\text { Elem } \\
\text { Graduate }\end{array}$ & $\begin{array}{l}\text { Elem } \\
\text { Level }\end{array}$ & & \\
\hline & Mother & 1 & 3 & 5 & 11 & 5 & 8 & 33 & $84.62 \%$ \\
\hline & Father & 0 & 0 & 0 & 5 & 0 & 0 & 5 & $12.82 \%$ \\
\hline & Guardians & 0 & 0 & 0 & 0 & 0 & 1 & 1 & $2.56 \%$ \\
\hline & Total & 1 & 3 & 5 & 16 & 5 & 9 & 39 & $100 \%$ \\
\hline & & $2.56 \%$ & $7.69 \%$ & $12.82 \%$ & $41.03 \%$ & $12.82 \%$ & $23.08 \%$ & $100 \%$ & \\
\hline
\end{tabular}

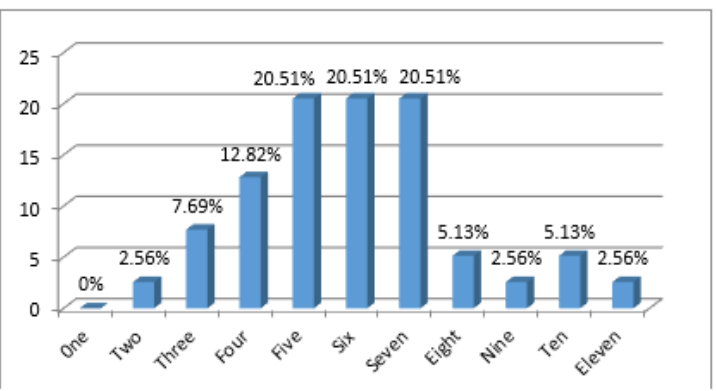

Figure 5. Number of household members

Type of Housing

Majority of the respondents' houses are made up of light materials. This represents $89.70 \%$ (35) as revealed in Figure 6. Only $10.30 \%$ (4) used semi-concrete materials in building their houses while none has a concrete house.

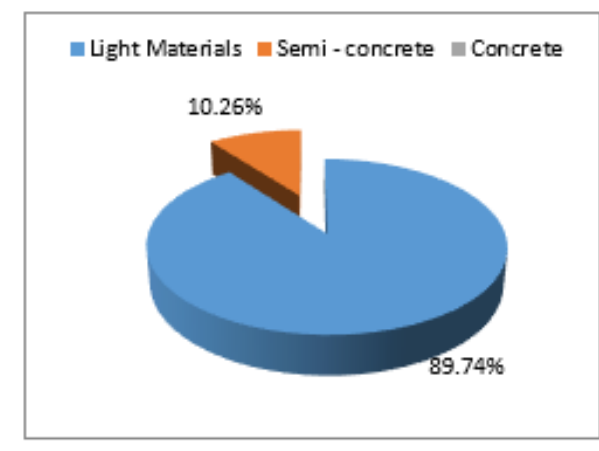

Figure 6. Type of Housing 


\section{Perception of the Recipients on the 4Ps Poverty Alleviation Program in the Philippines}

\section{Occupation}

Figure 7 reveals the occupation of the 4Ps respondents. It shows that $51.28 \%$ (20) are housewives, $10.26 \%$ (4) are helpers, $7.69 \%$ (3) are drivers, vendors, and laundry washers, respectively, and $2.56 \%$ (1) are barangay health workers, barangay tanod, construction workers, carpenters, masseurs, and bakers.

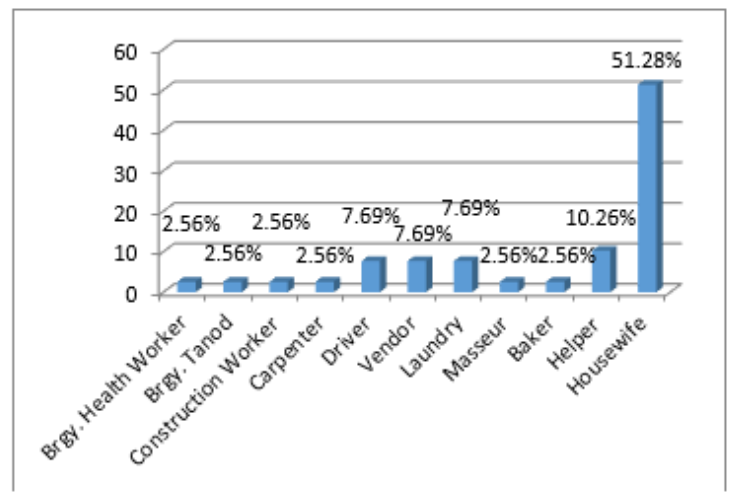

Figure 7. Occupation of 4Ps respondents

\section{Household Monthly Income}

Figure 8 shows that $56.41 \%$ (22) of the respondents has a household monthly income of Php 3,998.00 and below, $38.46 \%$ (15) earn from Php 3,999.00-8,998.00, both of which are considered below poverty line and $5.13 \%$ (2) has an income of Php 8,999.00-13,998.00 considered as within the poverty line. No one earns from Php 13,999.00 and above considered to be above poverty line.

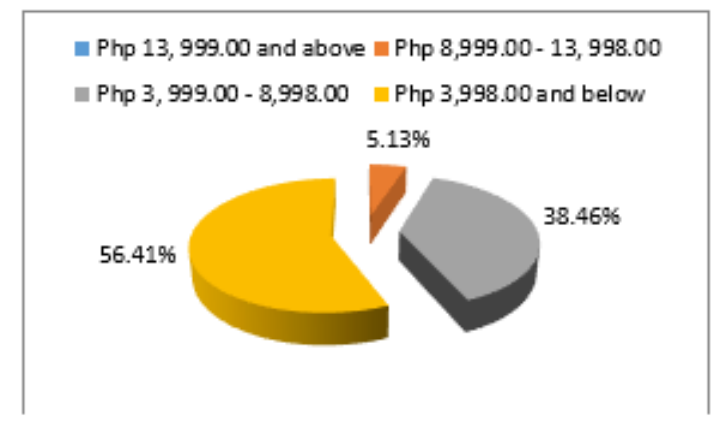

Figure 8. Household monthly income

\section{Ownership of Assets}

The different assets of the 4Ps respondents are revealed in Figure 9. This shows that $84.62 \%$ (33) own their house while only $2.56 \%$ (1) own the land. With regard to their appliances, $61.54 \%$ (24) have television sets, $56.41 \%$ (22) have radios, $20.51 \%$ (8) have refrigerators, $5.13 \%$ (2) have pedicabs, $7.69 \%$ (3) have DVD components, and $2.56 \%$ (1) have electric fans.

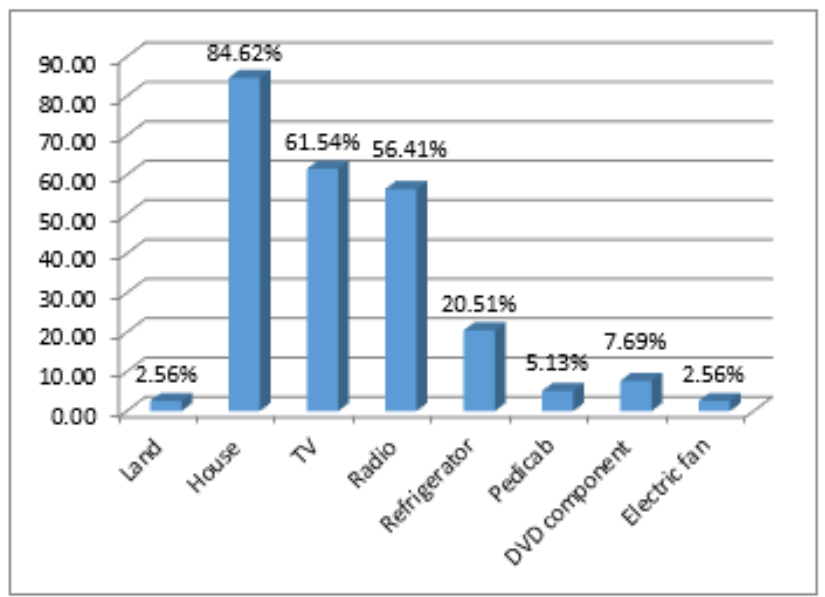

Figure 9. Ownership of Assets

Water, Electricity, and Sanitation Facilities

The researchers found that all 39 respondents have access to water, electricity, and sanitation facilities such as toilets. However, Figure 10 shows that only $82.05 \%$ (32) have their own water source while $17.95 \%$ (7) buy from sources in the neighborhood. Moreover, $74.36 \%$ (29) have electricity at home while $25.64 \%$ (10) has none, opting to tap electrical connections of neighbors or use kerosene instead. Moreover, 59.97\% (23) have their own toilets while 41.03 (16) make use of the toilets of relatives and neighbors.

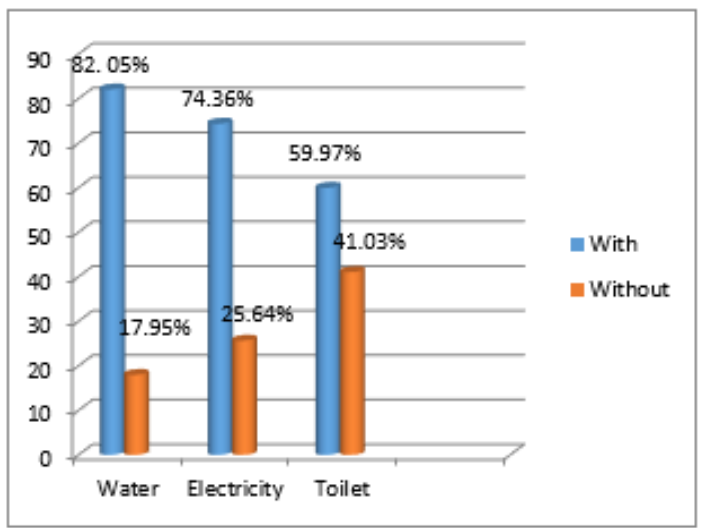

Figure 10. Water source, electricity connection, and sanitation facilities

From among the 32 respondents with own water source, $21.88 \%$ (7) use water from deep wells while $78.13 \%$ use water from the local water pipe system as shown in Figure 11 .

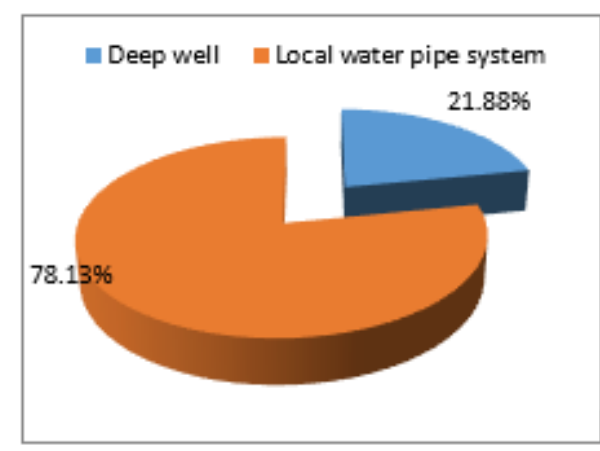

Figure 11. Type of water source 


\section{B. Perceived Extent of Implementation of the 4Ps}

The extent of the implementation of the 4Ps covered its policy implementation in terms of its health and education programs.It also shows if the objectives in terms of social assistance and social development are met.

The researchers made use of mean and standard deviation in interpreting the data. Tabular presentations and discussions follow.

Table 2. Mean value for health conditions

\begin{tabular}{|l|c|c|c|c|c|c|}
\hline \multirow{2}{*}{ Program Conditions (Health) } & \multicolumn{5}{|c|}{ Health } & \multirow{2}{*}{ Mean } \\
\cline { 2 - 6 } & 5 & 4 & 3 & 2 & 1 & \\
\hline $\begin{array}{l}\text { 1. Pre-natal check-up of } \\
\text { pregnant mother }\end{array}$ & 18 & 6 & 1 & 0 & 0 & 4.68 \\
\hline $\begin{array}{l}\text { 2. Immunization of 0-5 year } \\
\text { old children }\end{array}$ & 23 & 5 & 0 & 0 & 0 & 4.82 \\
\hline $\begin{array}{l}\text { 3. Weight monitoring 0 - 5 } \\
\text { year old }\end{array}$ & 19 & 6 & 3 & 0 & 1 & 4.45 \\
\hline $\begin{array}{l}\text { 4. Check - up of 0 - 5 year } \\
\text { old children }\end{array}$ & 16 & 9 & 5 & 1 & 1 & 4.19 \\
\hline $\begin{array}{l}\text { 5. Deworming of children 6 - } \\
\text { 14 year old }\end{array}$ & 21 & 5 & 8 & 2 & 0 & 4.25 \\
\hline
\end{tabular}

Table 3. Mean value for education conditions

\begin{tabular}{|l|c|c|c|c|c|c|}
\hline \multirow{2}{*}{$\begin{array}{c}\text { Program Conditions } \\
\text { (Education) }\end{array}$} & 5 & 4 & 3 & 2 & 1 & \multirow{5}{*}{ Mean } \\
\cline { 2 - 6 } & 16 & 6 & 0 & 0 & 3 & 4.28 \\
\hline $\begin{array}{l}\text { 1. Attendance of Day Care 3 - } \\
\text { 5 year old }\end{array}$ & 17 & 4 & 3 & 3 & 3 & 3.97 \\
\hline $\begin{array}{l}\text { 2. Primary and Secondary } \\
\text { Education of 6-14 yearold }\end{array}$ & 23 & 6 & 9 & 1 & 0 & 4.31 \\
\hline 3. Attendance of Parents to: & 17 & 7 & 13 & 1 & 1 & 3.97 \\
\hline $\begin{array}{l}\text { a. Family development } \\
\text { sessions }\end{array}$ & & & & \\
\hline b. Community activities & & &
\end{tabular}

Table 4. Mean value for social assistance

\begin{tabular}{|l|c|c|c|c|c|c|}
\hline \multirow{2}{*}{$\begin{array}{c}\text { Objectives (Social } \\
\text { Assistance) }\end{array}$} & \multicolumn{5}{|c|}{ Social Assistance } & \multirow{2}{*}{ Mean } \\
\cline { 2 - 7 } & 5 & 4 & 3 & 2 & 1 & \\
\hline 1. Enough & 9 & 11 & 14 & 2 & 3 & 3.54 \\
\hline 2. Appropriately spent & 16 & 11 & 12 & 0 & 0 & 4.10 \\
\hline 3. Released on time & 17 & 6 & 12 & 0 & 4 & 3.82 \\
\hline 4. Properly liquidated & 13 & 5 & 12 & 2 & 7 & 3.38 \\
\hline $\begin{array}{l}\text { 5. Helps augment financial } \\
\text { needs }\end{array}$ & 20 & 5 & 14 & 0 & 0 & 4.15 \\
\cline { 3 - 6 } & & & & & 3.80 \\
\hline
\end{tabular}

Table 5. Mean value for social development

\begin{tabular}{|l|c|c|c|c|c|c|}
\hline \multirow{2}{*}{$\begin{array}{l}\text { Objectives (Social } \\
\text { Development) }\end{array}$} & \multicolumn{5}{|c|}{ Social Development } & \multirow{2}{*}{ Mean } \\
\cline { 2 - 6 } & 5 & 4 & 3 & 2 & 1 & \\
\hline 1. Organizes parent leaders & 21 & 6 & 12 & 0 & 0 & 4.23 \\
\hline $\begin{array}{l}\text { 2. Establishes projects like } \\
\text { community garden }\end{array}$ & 8 & 15 & 12 & 2 & 2 & 3.64 \\
\hline $\begin{array}{l}\text { 3. Coordinates with school } \\
\text { projects such as } \\
\text { "GulayansaPaaralan" }\end{array}$ & 13 & 14 & 11 & 1 & 0 & 4.00 \\
\hline $\begin{array}{l}\text { 4. Monitors attendance of } \\
\text { pupils and students }\end{array}$ & 19 & 7 & 11 & 2 & 0 & 4.10 \\
\hline 5. Monitors the health & 22 & 7 & 10 & 0 & 0 & 4.31 \\
\hline
\end{tabular}

Table 6. Extent of Implementation of 4Ps in terms of its policy and objectives

\begin{tabular}{|l|c|c|c|l|}
\hline & Mean & $\begin{array}{c}\text { Standard } \\
\text { Deviation }\end{array}$ & N & Description \\
\hline \multicolumn{1}{|c|}{ Policy } & & & & \\
\hline Health & 4.22 & 0.859 & 37 & Implemented \\
\hline Education & 4.13 & 0.868 & 39 & Implemented \\
\hline Objectives & & & & \\
\hline Social Assistance & 3.80 & 0.736 & 39 & Implemented \\
\hline Social Development & 4.06 & 0.721 & 39 & Implemented \\
\hline
\end{tabular}

Table 6 shows the perceived extent of implementation of the 4Ps in terms of its policy and objectives at intervals of 1.33: 1.00-2.32 for Not Implemented; 2.33-3.65 for Partly Implemented and 3.66-5.00 for Implemented.

Results show that both the 4Ps policy on education and health and its objectives for social assistance and social development are implemented with a mean value falling between 3.66-5.00. Its policy on health got a mean value of 4.22 with standard deviation of 0.859 while its policy on education got a mean value of 4.13 with a standard deviation of 0.868 . In terms of its objectives, social assistance got a mean value of 3.80 with a standard deviation of 0.736 and social development got a mean value of 4.06 with a standard deviation of 0.721 .

The disparity of the mean value on health conditions found on Tables 2 and 6 can be attributed to items on health unanswered by two respondents.

\section{Profile of the Recipients and the Perceived Extent of $4 P$ s Implementation}

To establish the relationship of the profile of 4Ps respondents and the extent of implementation of the program in terms of its policy and objectives, the researchers made use of correlation coefficient after tabulating and analyzing data through the Statistical Package for Social Sciences (SPSS) program.

Table 7 shows that the perception of the respondents on the implementation of the 4Ps health program has no significant relationship to their position in the family with eta value of 0.215 and p-value of 0.448 , no significant relationship with respect to their education with eta value of 0.328 and p-value of 0.595 , no significant relationship to their type of housing with eta value of 0.272 and $p$-value of 0.27 , no significant relationship to their occupation with eta value of 0.626 and p-value of 0.14 , no significant relationship to their ownership of house with eta value of 0.287 and p-value of 0.085 , no significant relationship to their water source with eta value of 0.102 and p-value of 0.546 , and no significant relationship to their source of electricity with eta value of 0.143 and p-value of 0.397 . Land ownership was not considered a variable in relation to the implementation of the 4Ps policy on health.

As can be seen, all the corresponding $\mathrm{p}$-values for each category mentioned were greater than the set level of significance of $5 \%$. Hence, the null hypothesis was accepted. This means that the position in the family of respondents, educational attainment, type of housing, occupation, ownership of house, and source of water and electricity do not considerably affect the implementation of the 4Ps policy on health.

However, the perception of the respondents on the implementation of the 4Ps health program has a significant relationship to their ownership of sanitation facilities such as 
toilets with eta value of 0.604 and p-value of 0 . Therefore, the null hypothesis of no significant correlation is rejected. This means that ownership of sanitation facilities is a significant factor in the implementation of 4Ps health program.

Table 7. Profile of recipients and the 4Ps health program implementation

\begin{tabular}{|l|c|c|}
\hline \multirow{2}{*}{ Profile } & \multicolumn{2}{|c|}{$\begin{array}{c}\text { Extent of Implementation (Health } \\
\text { Program) }\end{array}$} \\
\cline { 2 - 3 } & eta & p-value \\
\hline Position & 0.215 & 0.448 \\
\hline Education & 0.328 & 0.595 \\
\hline Housing & 0.272 & 0.27 \\
\hline Occupation & 0.626 & 0.14 \\
\hline Land & $*$ & - \\
\hline House & 0.287 & 0.085 \\
\hline Water & 0.102 & 0.546 \\
\hline Electricity & 0.143 & 0.397 \\
\hline Sanitation & 0.604 & $0 * *$ \\
\hline
\end{tabular}

Table 8 shows that the perception of the respondents on the implementation of the 4Ps education program has no significant relationship to their position in the family with eta value of 0.269 and $p$-value of 0.259 , no significant relationship to their education with eta value of 0.318 and $\mathrm{p}$ value of 0.596 , no significant relationship to their type of housing with eta value of 0.272 and p-value of 0.249 , no significant relationship to their occupation with eta value of 0.614 and p-value of 0.131 , no significant relationship to their ownership of land with eta value of 0 and p-value of 1 , no significant relationship to their water source with eta value of 0.136 and p-value of 0.408 , and no significant relationship to their source of electricity with eta value of 0.177 and p-value of 0.281 .

Since all the corresponding p-values for each category mentioned were greater than the set level of significance of $5 \%$, the null hypothesis was accepted. This means that the position in the family of respondents, educational attainment, type of housing, occupation, land ownership, and source of water and electricity do not considerably affect the implementation of the 4Ps policy on education.

On the other hand, the perception of the respondents on the implementation of the 4Ps education program has significant relationship to their ownership of house with eta value of 0.394 and p-value of 0.013 and sanitation facilities such as toilets with eta value of 0.593 and p-value of 0 . Therefore, the null hypothesis of no significant correlation was rejected. This means that respondents perceive ownership of house and sanitation facilities as significant factors in the implementation of the 4Ps education program.

Table 8. Profile of recipients and the 4Ps education program implementation

\begin{tabular}{|l|c|c|}
\hline \multirow{2}{*}{ Profile } & \multicolumn{2}{c|}{$\begin{array}{c}\text { Extent of Implementation (Education } \\
\text { Program) }\end{array}$} \\
\cline { 2 - 3 } & eta & p-value \\
\hline Position & 0.269 & 0.259 \\
\hline Education & 0.318 & 0.596 \\
\hline Housing & 0.272 & 0.249 \\
\hline Occupation & 0.614 & 0.131 \\
\hline Land & 0 & 1 \\
\hline House & 0.394 & $0.013^{* *}$ \\
\hline Water & 0.136 & 0.408 \\
\hline Electricity & 0.177 & 0.281 \\
\hline Sanitation & 0.593 & $0 * *$ \\
\hline
\end{tabular}

Table 9 shows that the perception of the respondents on the implementation of the 4Ps objective to provide social assistance has no significant relationship to their education with eta value of 0.236 and $p$-value of 0.853 , no significant relationship to their type of housing with eta value of 0.304 and p-value of 0.174 , no significant relationship to their occupation with eta value of 0.656 and $p$-value of 0.058 , no significant relationship to their ownership of land with eta value of 0.223 and $p$-value of 0.172 , no significant relationship to their water source with eta value of 0.055 and p-value of 0.739 , and no significant relationship to their source of electricity with eta value of 0.274 and $p$-value of 0.091 .

All the corresponding p-values for each category mentioned were greater than the set level of significance of $5 \%$. Therefore, the null hypothesis was accepted. This means that the educational attainment of the respondents, type of housing, occupation, land ownership, and source of water and electricity do not considerably affect the implementation of the 4Ps objective to provide social assistance.

However, the perception of the respondents on the implementation of the 4Ps social assistance objective has a significant relationship to their position in the family with eta value of 0.404 and p-value of 0.04 , ownership of house with eta value of 0.352 and p-value of 0.028 and sanitation facilities such as toilets with eta value of 0.444 and p-value of 0.005 . Therefore, the null hypothesis of no significant correlation was rejected. This means that respondents perceive position in the family, ownership of house and sanitation facilities as significant factors in the implementation of the 4Ps objective on social assistance.

Table 9. Profile of recipients and the 4Ps social assistance objective

\begin{tabular}{|l|c|c|}
\hline \multirow{2}{*}{ Profile } & \multicolumn{2}{c|}{$\begin{array}{c}\text { Extent of Implementation (Social } \\
\text { Assistance) }\end{array}$} \\
\cline { 2 - 3 } & eta & p-value \\
\hline Position & 0.404 & $0.04 * *$ \\
\hline Education & 0.236 & 0.853 \\
\hline Housing & 0.304 & 0.174 \\
\hline Occupation & 0.656 & 0.058 \\
\hline Land & 0.223 & 0.172 \\
\hline House & 0.352 & $0.028^{* *}$ \\
\hline Water & 0.055 & 0.739 \\
\hline Electricity & 0.274 & 0.091 \\
\hline Sanitation & 0.444 & $0.005^{* *}$ \\
\hline
\end{tabular}

Table 10 shows that the perception of the respondents on the implementation of the 4Ps objective for social development has no significant relationship to their position in the family with eta value of 0.23 and p-value of 0.378 , no significant relationship to their educational attainment with eta value of 0.201 and p-value of 0.922 , no significant relationship to their type of housing with eta value of 0.368 and p-value of 0.073 , no significant relationship to their occupation with eta value of 0.633 and p-value of 0.093 , no significant relationship to their ownership of land with eta value of 0.033 and $p$-value of 0.843 , no significant relationship to their water source with eta value of 0.057 and p-value of 0.732 , and no significant relationship to their source of electricity with eta value of 0.201 and p-value of 0.22 .

All the corresponding p-values for each category mentioned were greater than the set level of significance of $5 \%$. Therefore, the null hypothesis was accepted. This means that the position in the family of the respondents, their educational attainment, type of housing, occupation, 
land ownership, and source of water and electricity do not considerably affect the implementation of the 4Ps objective for social development.

However, the perception of the respondents on the implementation of the 4Ps objective for social development has a significant relationship to their ownership of house with eta value of 0.043 and $p$-value of 0.027 and sanitation facilities such as toilets with eta value of 0.652 and p-value of 0 . Therefore, the null hypothesis of no significant correlation was rejected. This means that respondents perceive ownership of house and sanitation facilities as significant factors in the implementation of the 4Ps objective on social assistance.

Table 10. Profile of recipients and the 4Ps social development objective

\begin{tabular}{|l|c|c|}
\hline \multirow{2}{*}{ Profile } & \multicolumn{2}{|c|}{$\begin{array}{c}\text { Extent of Implementation (Social } \\
\text { Development) }\end{array}$} \\
\cline { 2 - 3 } & eta & p-value \\
\hline Position & 0.23 & 0.378 \\
\hline Education & 0.201 & 0.922 \\
\hline Housing & 0.368 & 0.073 \\
\hline Occupation & 0.633 & 0.093 \\
\hline Land & 0.033 & 0.843 \\
\hline House & 0.043 & $0.027 * *$ \\
\hline Water & 0.057 & 0.732 \\
\hline Electricity & 0.201 & 0.22 \\
\hline Sanitation & 0.652 & $0 * *$ \\
\hline
\end{tabular}

Table 11 shows that the number of household members of the respondents has no significant relationship to the implementation of the 4Ps policy on health with Pearson's $r$ value of -0.024 and $p$-value of 0.886 , no significant relationship to the implementation of the policy on education with Pearson's $r$ value of 0.118 and p-value of 0.473 , no significant relationship to the implementation of its objective for social assistance with Pearson's $r$ value of 0.139 and p-value of 0.399 , and no significant relationship to the implementation of its objective for social development with Pearson's $r$ value of -0.041 and p-value of 0.806 .

Since all the corresponding p-values for each category mentioned were greater than the set level of significance of $5 \%$, the null hypothesis was accepted. This means that the number of household members does not considerably affect the implementation of the 4Ps policy on health and education as well as its objective for social assistance and social development.

Table 11. Number of household members and implementation of 4Ps policy and objectives

\begin{tabular}{|l|l|l|c|c|}
\hline \multicolumn{2}{|c|}{} & \multicolumn{2}{|c|}{ Household Members } \\
\cline { 3 - 5 } \multicolumn{2}{|c|}{} & Pearson's $r$ & $\begin{array}{c}\text { p- } \\
\text { value }\end{array}$ \\
\hline \multirow{3}{*}{$\begin{array}{l}\text { Extent of } \\
\text { Implementation }\end{array}$} & $\begin{array}{c}\text { Program } \\
\text { Conditions }\end{array}$ & Health & -0.024 & 0.886 \\
\cline { 3 - 5 } & \multirow{2}{*}{ Objectives } & $\begin{array}{l}\text { Social } \\
\text { Assistance }\end{array}$ & -0.139 & 0.118 \\
\cline { 3 - 5 } & $\begin{array}{l}\text { Social } \\
\text { Development }\end{array}$ & -0.041 & 0.399 \\
\hline
\end{tabular}

Table 12 shows that the household monthly income of the respondents has no significant relationship to the implementation of the 4Ps policy on health with gamma value of -0.196 and $p$-value of 0.353 , no significant relationship to the implementation of the policy on education with gamma value of -0.219 and p-value of 0.212 , no significant relationship to the implementation of its objective for social assistance with gamma value of -0.157 and p-value of 0.443 , and no significant relationship to the implementation of its objective for social development with gamma value of -0.326 and $p$-value of 0.071 .

Since all the corresponding p-values for each category mentioned were greater than the set level of significance of $5 \%$, the null hypothesis was accepted. This means that the household monthly income of the respondents does not considerably affect the implementation of the 4Ps policy on health and education as well as its objective for social assistance and social development.

Table 12. Household monthly income and implementation of 4Ps policy and objectives

\begin{tabular}{|c|c|c|c|c|}
\hline & \multicolumn{2}{|c|}{ Income } \\
\hline & & & Gamma & p-value \\
\hline \multirow{4}{*}{$\begin{array}{c}\text { Extent of } \\
\text { Implementation }\end{array}$} & \multirow{2}{*}{$\begin{array}{c}\text { Program } \\
\text { Conditions }\end{array}$} & Health & -0.196 & 0.353 \\
\hline & & Education & -0.219 & 0.212 \\
\hline & \multirow{2}{*}{ Objectives } & $\begin{array}{l}\text { Social } \\
\text { Assistance }\end{array}$ & -0.157 & 0.443 \\
\hline & & $\begin{array}{l}\text { Social } \\
\text { Development }\end{array}$ & -0.326 & 0.071 \\
\hline
\end{tabular}

Findings show that though the 4Ps policy on education and health and its objectives for social assistance and social development are implemented, only three factors in the profile of the respondents have a significant relationship on the said implementation. These include ownership of sanitation facilities such as toilets, ownership of their house, and position in the family of respondents.

Ownership of sanitation facilities such as toilets consistently affects both the implementation of the 4Ps policy and objectives. This implies that the 4Ps policy on health and education as well as objectives for social assistance and social development will be better implemented if more respondents have their own sanitation facilities.

Findings also show that there will be a better implementation of the 4Ps education program and its objective to provide social assistance and development if respondents have their own houses.

Furthermore, position in the family has a significant relationship only in terms of the 4Ps implementation of its objective to provide social assistance. Since $84.62 \%$ of the respondents are mothers, this implies that the perception of the mothers on the social assistance given considerably affects the attainment of this objective.

\section{CONCLUSION AND RECOMMENDATIONS}

It could be concluded from this study that the 4Ps is perceived to be implemented by the recipients. The findings, likewise, reveal that only a few profile factors are significant to their perception of the program's implementation on its policy and objectives. These include the ownership of sanitation facilities in relation to both the policy on health and education and its objectives on social assistance and development, ownership of their house in relation its policy on education and its objectives on social assistance and development, and their position in the family on the implementation of its objective on social assistance.

However, there are several limitations in this study. The population of the recipients that participated in this study with regard to gender was unequal. Moreover, the sample was taken only from one barangay in Tacloban City. Thus, this population may not mirror all the groups of recipients in 
Tacloban City, Eastern Visayas, and across the nation. The results then may not be generalizable to others.

Future studies should concentrate on finding largergroups to participate in similar studies. Further studies may also be conducted to see how the program has reached its goal on poverty reduction and social development and to seek if there is a need to expand the program as a way to fulfil the government's Millennium Development Goal.

\section{References}

[1] Curry, M. S., Cadiogan, A. T., \&Giugliano, R. G. (2013). Brazil's Bolsa Familia and the Philippines'" 4Ps" CCT Programs: Considering South-South Cooperation for Social Protection. Asia-Pacific Social Science Review, 13(1).

[2] De Leon, H. S. \& De Leon, H. M. Jr. (2011). Textbook on the Philippine Constitution Article 2, Section 9, p. 89. Quezon City: Rex Printing Co. Inc.

[3] Heyneman, S. P. (2004). International education quality. Economics of Education Review, 23(4), 441-452.

[4] Bacolod, M. P., \& Tobias, J. L. (2006). Schools, school quality and achievement growth: Evidence from the Philippines. Economics of education review, 25(6), 619-632.

[5] Heyneman, S. P., \& Loxley, W. A. (1983). The effect of primaryschool quality on academic achievement across twenty-nine high-and low-income countries. American Journal of sociology, 88(6), 1162 1194.

[6] Carnoy, M. (2006). Higher education and economic development: India, China, and the 21 st century. The Pan Asia Conference: focus on economic challenges. Stanford Center for International Development. Working Paper, (297).

[7] Catubig, M. C. L., Villano, R. A., \&Dollery, B. (2017). The administrative efficiency of conditional cash transfer programmes: evidence from the PantawidPamilyang Pilipino Program. Asia-Pacific Development Journal, 23(1), 133-158.

[8] Abellanosa, Kirk Andrew (2014). “The Impact of 4P's in Tagbina II District," Published in Government and Non-Profit Slide Share December 14, 2014

[9] Baez, J. E., \& Camacho, A. (2011). Assessing the long-term effects of conditional cash transfers on human capital: evidence from Colombia. The World Bank.

[10] Catubig, M. C. L., \&Villano, R. A. (2017). Conditional Cash Transfer and School Outcomes: An Evaluation of the PantawidPamilyang Pilipino Program in Davao Oriental, Philippines. Asian Economic Journal, 31(4), 403-421.

[11] Conchada, M. I. P., \&Tiongco, M. (2014, March). Optimal Allocation of School and Health Resources for Effective Delivery of the Conditional Cash Transfer Program in Bagac, Bataan. In DLSU Research Congress, De La Salle University, Manila, Philippines $\operatorname{March}$ (Vol. 6).

[12] Chaudhury, N., Okamura, Y., Chaudhury, N., \& Okamura, Y. (2012). Conditional cash transfers and school enrollment: impact of the conditional cash transfer program in the Philippines (No. 71904). The World Bank.

[13] Montilla, M. M., Delavin, E. A., Villanueva, R. M., \& Turco, R. A. (2015). Pantawidpamilyang Pilipino program (4Ps): Assistance to pupil's education. Asia Pacific Journal of Education, Arts, and Sciences, 2 (3), 1-5.

[14] Reyes, C. M., Tabuga, A. D., Mina, C. D., \&Asis, R. D. (2015). Promoting inclusive growth through the 4Ps (No. RPS 201501). Manila: Philippine Institute for Development Studies.

[15] Sasaki, K., Diaz, N. T., \&Brazal, P. J. I. (2019). A study on attendance, academic performance and completion rate for the PantawidPamilyang Pilipino Program recipients in a selected secondary school. International E-Journal of Advances in Education, 5(13), 44-49.

[16] Tabuga, A. D., \& Reyes, C. M. (2012). Conditional cash transfer program in the Philippines: is it reaching the extremely poor? (No. 2012-42). PIDS Discussion Paper Series.

[17] Frufonga, R. F. (2015). The PantawidPamilyang Pilipino Program (4Ps) in Iloilo, Philippines: an evaluation. Asia Pac J Multidisciplinary Res, 3, 59-65.

[18] Fernandez, L., \&Olfindo, R. (2011). Overview of the Philippines' Conditional Cash Transfer Program: The PantawidPamilyang Pilipino Program. Philippine social protection note (2).

[19] Solow, R. M. (1956). A contribution to the theory of economic growth. The quarterly journal of economics, 70(1), 65-94.

[20] Bass, H. (2008) Ragnar Nurkse's Development Theory: Influences and Perceptions. Retrieved from

https://www.academia.edu/3023481/Ragnar_Nurkses_Development_ Theory_Influences_and_Perceptions

[21] Rostow, W. W. (1960). The Stages of Growth: A Non-Communist Manifesto. Retrieved from http://people.cedarville.edu/employee/wheelerb/macro/ldc theory/ecn dev.html

[22] Hoddinott, J., Adato, M., Besley, T., \& Haddad, L. J. (2001). Participation and poverty reduction: issues, theory, and new evidence from South Africa (No. 583-2016-39542).

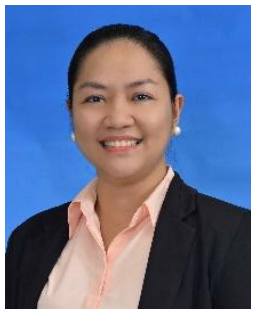

extension studies.
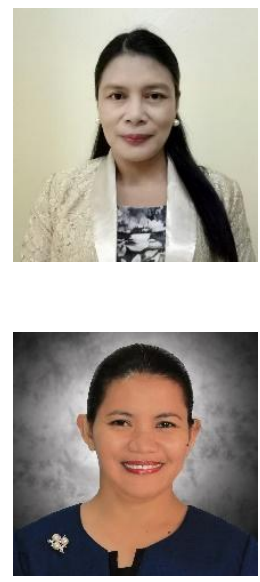

university.

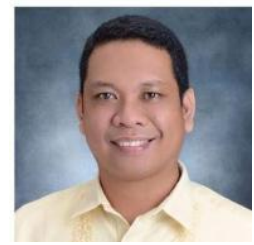

Prof. Alma Sonia Q. Sanchez-Dandayis an Associate Professor of Leyte Normal University and a lawyer engaged in a limited private practice of law. She holds the degree of Doctor of Philosophy in Education major in Educational Programs Management and is actively involved in several research and extension projects of the university. Her research interests include mother tongue instruction, early childhood education, legal literacy, educational policies, and poverty alleviation

Prof. Lorena M. Ripaldais an Assistant Professor of the Leyte Normal University and the current Bachelor of Elementary Education Program Head. She is also the Manager of the LNU Preparatory Learning Center. She had been the Research and Extension Coordinator of the LNU- Integrated Laboratory School. Her academic interests include mother tongue instruction and curriculum writing.

Prof. Maria Teresa L. Delima is from Tacloban City, Philippines. She was a public elementary school teacher who handled Grades One and Two classes. She was also a Supervising Teacher Educator of the Leyte Normal UniversityIntegrated Laboratory School (LNU-ILS). Presently, she is an Assistant Professor teaching professional education subjects at the same

Prof. Romyr L. Gabonis an Assistant Professor of the Leyte Normal University currently enrolled in Doctor of Education, major in Physical Education, Curriculum, and Instruction. He had been the Head of the Music, Arts, Physical Education, Health (MAPEH) and the Humanities Unit of the university for five years. 